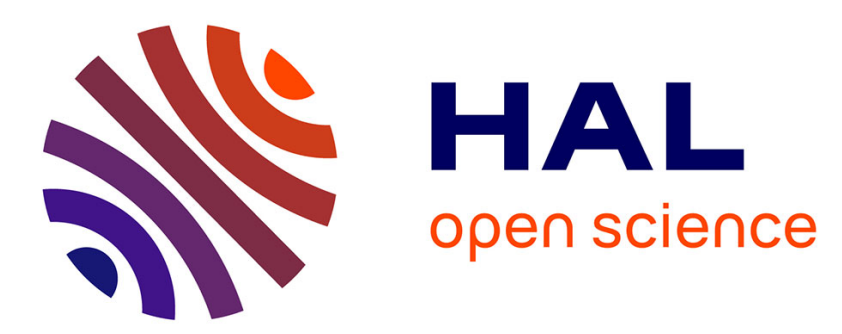

\title{
Comments on "Prevented Mortality and Greenhouse Gas Emissions from Historical and Projected Nuclear Power"
}

Xavier Rabilloud

\section{- To cite this version:}

Xavier Rabilloud. Comments on "Prevented Mortality and Greenhouse Gas Emissions from Historical and Projected Nuclear Power". Environmental Science and Technology, 2013, indisponible au 14 novembre 2013 (parution papier à venir). 10.1021/es404245a . hal-00904178

\section{HAL Id: hal-00904178 \\ https://hal.science/hal-00904178}

Submitted on 14 Nov 2013

HAL is a multi-disciplinary open access archive for the deposit and dissemination of scientific research documents, whether they are published or not. The documents may come from teaching and research institutions in France or abroad, or from public or private research centers.
L'archive ouverte pluridisciplinaire HAL, est destinée au dépôt et à la diffusion de documents scientifiques de niveau recherche, publiés ou non, émanant des établissements d'enseignement et de recherche français ou étrangers, des laboratoires publics ou privés. 


\title{
Comments on "Prevented Mortality and Greenhouse Gas Emissions from Historical and Projected Nuclear Power"
}

\author{
Xavier Rabilloud \\ xavier.rabilloud@yahoo.fr
}

This document is the unedited author's version of a submitted work that was subsequently accepted for publication in Environmental Science and Technology, copyright @ American Chemical Society after peer review. To access the final edited and published work (publication date : November 12, 2013), see http://dx.doi.org/10.1021/es404245a 
Using a nuclear mortality factor ${ }^{1}$ based on ExternE-v5 ${ }^{2}$, Kharecha and Hansen (K\&H) purportedly calculated the mortality prevented by using nuclear power rather than fossil fuels, for both the "historical" (1971-2009) nuclear capacity and future projections (2010-2050). ${ }^{3}$ In this narrow space I present some deep flaws of their analysis.

\section{A/ Gross errors}

A.1. ExternE's FAQ states, "Chernobyl-type plants would not be built today.... Results generated for a pressurized water reactor (PWR) type plant are not applicable to a Chernobyl-type plant". ${ }^{4}$ ExternE-v5 dealt only with "future" PWR reactors. Consequently, Chernobyl and its health consequences are entirely outside the scope of the nuclear mortality factor K\&H use. Applying this mortality factor to the "historical" period (1971-2009) is thus outright absurd. In so doing, $\mathrm{K} \& \mathrm{H}$ replace the occurred Chernobyl major accident on an RBMK reactor with a hypothetical future major accident on a PWR reactor whose probability is deemed equal to $9,5 \times 10^{-6}$ per reactor-year.

A.2. K\&H claim erroneously that the number of deaths caused by "historical" nuclear power they calculate (4900) "could be a major overestimate relative to the empirical value (by 2 orders of magnitude)", when compared with the "43 deaths... conclusively attributable to radiation from Chernobyl as of 2006" according to the United Nations Scientific Committee on the Effects of Atomic Radiation (UNSCEAR).

A.2.1. K\&H mistake the deaths caused only by severe reactor accidents for those caused by nuclear power "cradle-to-grave". Indeed, the nuclear mortality factor includes deaths attributable to all stages from mine to waste disposal, not only to accidents during generation.

A.2.2. $\mathrm{K} \& \mathrm{H}$ only refer to the number of deaths already occurred (43) and not to the estimated total number of expected deaths (approximately 9000) from Chernobyl as endorsed by UNSCEAR et al. in 2006. K\&H ignore that deaths expected in the future but attributable to an already occurred accident belong to the "historical" period of their analysis, and not to the projection period, since their cause lies in the past. And yet, ExternE-v5 rightly dealt with delayed deaths.

A.2.3. $\mathrm{K} \& H$ do not overestimate, but on the contrary underestimate the deaths attributable to "historical" nuclear power, at the very least by a factor 3. Indeed, the two most severe accidents considered by ExternE-v5 yield 9 immediate deaths ( 3 times less than the 28 Chernobyl "early" deaths acknowledged by UNSCEAR) and 17452 delayed deaths, weighted by very low probabilities per reactor- 
year. Thus, assuming 14000 reactor-years until 2010, the mortality factor yields less than 3000 deaths caused by nuclear accidents, 3 times less than the 9000 fatal cancers that UNSCEAR et al. expected after Chernobyl.

A.3. K\&H improperly calculate the upper value of all ranges for the number of deaths prevented by nuclear power by subtracting a mean value (for nuclear) to the upper value of a $95 \%$ confidence interval (for coal and gas).

\section{B/ Suppressing crucial uncertainties altogether}

By using a nuclear mortality factor whose (mean) value is provided without any confidence interval, $\mathrm{K} \& \mathrm{H}$ assume zero uncertainty. Yet there are high uncertainties within two key constitutive elements of the nuclear mortality factor: (B.1) the health effects of low doses of radioactivity released during both normal operation and accidental situations at nuclear facilities, and (B.2) the probability of future major nuclear accidents.

\section{B.1. Crucial uncertainties: the health effects of low doses of radioactivity}

\section{B.1.1. Although their calculation does not take into account any estimate of Chernobyl death toll,} $\mathrm{K} \& \mathrm{H}$ discuss one of them (UNSCEAR 2008) only, conveniently the lowest one, despite it is much scientifically disputed.

For $\mathrm{K} \& \mathrm{H}$, "the 2008 UNSCEAR report... represents a rigorous scientific assessment performed by expert scientists from 27 countries (including the countries most affected by the accident)". ${ }^{5}$ Wrong: only in 2012 were Belarus and Ukraine accepted within UNSCEAR, although they applied in $2007 .{ }^{6}$ No Ukrainian or Belarussian scientist collaborated to the 2008 UNSCEAR report.

The official objective of the International Atomic Energy Agency (IAEA) is "to accelerate and enlarge the contribution of atomic energy to peace, health and prosperity throughout the world" ${ }^{7}$, in brief: to promote nuclear power. Now, 2008 UNSCEAR's assessment is essentially the same as 2006 IAEA-led Chernobyl Forum's; accordingly, its lead author is IAEA's Mikhaïl Balonov, who also acted as Chernobyl Forum's scientific secretary.

Chernobyl Forum asserted that "up to 4000 people could eventually die of radiation exposure" from Chernobyl. ${ }^{8}$ Truncating its own data, it more than halved the estimate (8930 deaths in 95 years) of 
Chernobyl Forum's WHO (World Health Organization) expert group ${ }^{9}$, itself misrepresenting an old 1996 study by Cardis et al. who calculated "from 9785 to 22160 additional cancer and leukaemia deaths within 70 years." ${ }^{10}$ Even Cardis et al.'s own 2006 study yielded 17850 (95\% Cl: 7600-42 400) fatal cancers in Europe within 80 years. $^{11}$

Volodymyr Bebeshko, director-general of the Ukrainian Research Center for Radiation Medicine, refused to endorse the final report and said the Chernobyl Forum was "very clearly trying to minimize the

consequences." ${ }^{12}$ According to Nikolai Omelyanets, deputy head of the Ukrainian National Commission for Radiation Protection, "At least 500000 people... have already died out of the 2 million people who were officially classed as victims of Chernobyl in Ukraine... 34499 people who took part in the clean-up of Chernobyl have died in the years since the catastrophe" and the scientific information Ukraine sent "has been ignored by the IAEA and WHO."13

In 2006, the Belarussian radiophysicist Mikhaïl Malko estimated that Chernobyl will cause $116700(90 \%$ $\mathrm{Cl}: 36$ 980-196 300) additional fatal cancers in Europe during 1986-2056. ${ }^{14}$

John Gofman, a prominent Manhattan Project nuclear scientist and doctor of medicine, predicted 475000 fatal cancers from Chernobyl. ${ }^{15}$

\section{B.1.2. Health risks related to low doses of ionizing radiation are the central topic of a heated and ongoing scientific controversy.}

$\mathrm{K} \& \mathrm{H}$ use a nuclear mortality factor that relies upon ICRP's (International Commission on Radiological Protection) "linear no-threshold" (LNT) model, according to which any dose of radioactivity poses a health risk proportional to the dose, thus low at low doses. But, in the very words of UNSCEAR, "the inability to detect increases in risks at very low doses using epidemiological methods does not mean that the cancer risks are not elevated". ${ }^{16}$

To honestly evaluate the mortality possibly prevented by nuclear power, $\mathrm{K} \& \mathrm{H}$ should have taken into account all scientific views that, like them, "question the LNT model" - including those who accuse it of grossly underestimating the health effects of low doses of radiation.

\section{B.1.3. Considering the "supra-linear" and especially the "biphasic cell-response" models would have decreased by up to several orders of magnitude K\&H-calculated (mean) number of deaths possibly prevented by nuclear power.}


The supra-linear model estimates that damage per unit dose is greater at low levels. Prominent scientists have endorsed it, among whom Karl Morgan (the "father of health physics" and first president of ICRP). ${ }^{17}$

The biphasic cell-response model is proposed by the European Committee on Radiation Risk (ECRR), a group of 24 scientists from 12 countries. ${ }^{18}$ Its core is the deduction that low doses pose a health risk much higher than moderate doses. Former ICRP scientific secretary Jack Valentin deems relevant to publicly debate with ECRR's scientific secretary; he admits ICRP should have openly discussed ECRR's contributions. ${ }^{19}$ According to the French Institute for Radiological Protection and Nuclear Safety (IRSN), the biphasic cell-response model "raises fundamental questions with regard to radioprotection" and valid critics of the ICRP model, is worth scrutiny and calls for lots of further research. ${ }^{20}$

The biphasic cell-response model supports estimates of the Chernobyl death toll in the order of magnitude of 500000 to more than $1000000 .^{21,22}$ It must be kept in mind that the biphasic cell-response model also very significantly increases the number of deaths attributable to routine radioactive releases from normally operating nuclear facilities.

\section{B.2. Crucial uncertainties: the probability of major nuclear accidents}

\section{B.2.1. By applying to the worldwide $2010-2050$ projected nuclear fleet a mortality factor relying exclusively on PWR-reactor data, K\&H fail taking account of:}

- the continued operation of 11 old and ageing Chernobyl-like RBMK reactors, until between 2026 and 2035. Meanwhile, Aladar Stolmar, a nuclear engineer expert on RBMK reactors, warned in 2008 that "The RBMK reactors are just as unsafe now as they were before Chernobyl". ${ }^{23}$

- the continued operation of 23 Fukushima-like Mark-I BWR (boiling water) reactors in the USA. Prior to Fukushima, the OECD Committee on the Safety of Nuclear Installations stated, "For the BWRs, the core melt frequencies are in general lower than for the PWRs. In both PWRs and BWRs, accident management measures are very effective for prevention of core damage."24

B.2.2. PWR reactors may not be any safer. IRSN acknowledges that, "as for the existing nuclear plants, severe nuclear accidents have not been considered during their design." ${ }^{25}$ For the nuclear safety professor Balraj Seghal, "Severe accidents were not prescribed as safety design basis for current plants and they are not even so for the GEN III plants in USA and some other countries." ${ }^{26}$

B.2.3. After Fukushima, using a 1995-computed probability of major nuclear accidents is a blatant methodological mistake. Philippe Jamet, formerly IAEA's Director of Safety for Nuclear Facilities, says 
Fukushima "shows the limits of safety probabilistic studies" and adds that "the Fukushima situation, with such an addition of failures, has never been studied". ${ }^{27}$ Peter Lam, a former Administrative Judge at the US Nuclear Regulatory Commission, confirms that, until Fukushima, "multiple nuclear reactor core melts were deemed impossible, and have never been examined." ${ }^{28}$

\section{B.2.4. K\&H disregard the empirical frequency of major nuclear accidents, while it is an essential indicator for estimating their future frequency.}

A study of the Massachusetts Institute of Technology warns, "remaining uncertainties in PRA [Probabilistic Risk Assessment] methods and data bases make it prudent to keep actual historical risk experience in mind when making judgments about safety." 29

Wrongly counting Fukushima as one reactor meltdown, although 3 reactors melt, Jacques Repussard, IRSN's director-general, estimated, "statistics show that we are at 0.0002 severe nuclear accident by year, twenty times more than expected according to the probabilistic studies, which do not well take account of natural hazards and of the human factor." ${ }^{30}$

A nuclear physicist specialized in reactor physics, Bernard Laponche performed the correct calculation for major accidents (i.e., leading to significant radioactivity releases). ${ }^{31}$ The theoretical probability of one reactor undergoing a major accident (worldwide until 2010) is 0.014. But since 4 reactors (1 in Tchernobyl, 3 in Fukushima) underwent a major accident, the observed frequency of major nuclear reactor accidents is 286 times higher than what is predicted by PRA. Other scientists have drawn similar conclusions. ${ }^{29,32-35}$ Potential accidents or terrorist attacks at uranium mines, spent fuel storage pools, fuel fabrication facilities or during radioactive materials transportation are not even considered.

\section{B.2.5. Bypassing prominent nuclear regulators and scientists' warnings, $K \& H$ trust and use the absolute value of a risk probability.}

The French Nuclear Safety Authority (ASN) "considers the PRAs as a precious tool helping safety analysis" but warns "one shall not have excessive confidence in numerical results (in particular in their absolute values) and shall remain conscious of the uncertainties attached to these results." ${ }^{136}$

IRSN "highlights that the values of core melt probability... are an element of assessment enabling the hierarchisation of different sequences that may lead to [a core melt] situation. They must not be considered as absolute references." ${ }^{37}$ 
Yet, K\&H use PRA not for hierarchising safety concerns, but for estimating the number of future nuclear accidents and related fatalities.

\section{C/ Ignoring thoroughly assessed nuclear-free solutions}

$\mathrm{K} \& \mathrm{H}$ put France forward for its fast development of and heavy reliance on nuclear power. Now, a very thorough research shows France can divide its GHG emissions by 16 and phase-out nuclear by 2050 . $^{38}$ This scenario, called "Negawatt", was developped by 15 energy experts, three of whom were appointed to the group of "renowned experts" advising the council of the 2013 National Debate on Energy Transition launched by the French president. Despite conservative assumptions, Negawatt secures base load power needs and network equilibrium hour per hour all year long. A solid scientific case is made that even the most nuclear-addict developped country could "avoid dangerous climate change to protect young people, future generations, and nature" without endangering them with nuclear risks.

\section{Author information :}

Xavier Rabilloud is also an employee of Réseau "Sortir du nucléaire" (http://www.sortirdunucleaire.org). This citizen-funded independent NGO advocates the phasing-out of nuclear power in France and a low carbon energy policy based on efficiency, sobriety and renewable energies; it is a member and administrator of the Réseau Action Climat (http://www.rac-f.org), the French representative of the international Climate Action Network (http://www.climatenetwork.org). The present analysis is not endorsed and was neither commissioned nor funded by any of these or other organizations, and was carried out on a fully independent and benevolent basis.

\section{References:}

(1) Markandya, A.; Wilkinson, P. Electricity generation and health. The Lancet [Online] 2007, 370, 979-990. http://www.thelancet.com/journals/lancet/article/PIIS0140-6736\%2807\%2961253-7/abstract (accessed on September 22, 2013).

(2) CEPN. ExternE: External costs of Energy, vol 5: Nuclear, European Commission, Directorate-General XII Science, Research and Development, 1995.

http://www.externe.info/externe d7/sites/default/files/vol5.pdf (accessed on September 22, 2013).

(3) Kharecha, P.A.; Hansen, J.E. Prevented Mortality and Greenhouse Gas Emissions from Historical and Projected Nuclear Power. Environ. Sci. Technol. [Online] 2013, 47, 4889-4895. 
http://pubs.acs.org/doi/abs/10.1021/es3051197 (accessed on September 22, 2013).

(4) ExternE FAQ. http://www.externe.info/externe d7/?q=node/55 (accessed on September 22, 2013).

(5) Kharecha, P.A.; Hansen, J.E. Response to Comment on "Prevented Mortality and Greenhouse Gas Emissions from Historical and Projected Nuclear Power". Environ. Sci. Technol. [Online] 2013, 47 (12), 6718-6719. http://pubs.acs.org/doi/abs/10.1021/es402211m (accessed on September 22, 2013).

(6) United Nations General Assembly, Resolution 66/70, January 12, 2012. http://daccess-ddsny.un.org/doc/UNDOC/GEN/N11/463/02/PDF/N1146302.pdf?OpenElement (accessed on September 22, 2013).

(7) AIEA. Statute as amended up to 23 February 1989, 1989 (article II "Objectives"). http://www.iaea.org/About/statute.pdf (accessed on September 22, 2013).

(8) WHO/IAEA/UNDP. Chernobyl: the true scale of the accident - 20 Years Later a UN Report Provides Definitive Answers and Ways to Repair Lives, September 5, 2005.

http://www.iaea.org/newscenter/pressreleases/2005/prn200512.html (accessed on September 22, 2013).

(9) WHO. Health Effects of the Chernobyl Accident and Special Health Care Programmes, Report of the UN Chernobyl Forum Expert Group "Health", 2006, p 108.

http://www.who.int/ionizing radiation/chernobyl/WHO\%20Report\%20on\%20Chernobyl\%20Health\%20Effec ts\%20July\%2006.pdf (accessed on September 22, 2013).

(10) Pflugbeil, S. Chernobyl - Looking back to go forwards: the September 2005 IAEA Conference, Medicine, Conflict and Survival [Online] 2006, 22 (4), 299 - 309.

http://www.strahlentelex.de/Pflugbeil_Chernobyl-Commentary FMCS2006.pdf (accessed on September 22, 2013).

(11) Cardis, E et al., Estimates of the cancer burden in Europe from radioactive fallout from the Chernobyl accident, Int. J. Cancer [Online] 2006, 119, 1224-1235. http://www.ncbi.nlm.nih.gov/pubmed/16628547 (accessed on September 22, 2013).

(12) The Associated Press. Greenpeace Challenges UN on Chernobyl, April 19, 2006, http://www.themoscowtimes.com/news/article/greenpeace-challenges-un-on-chernobyl/205473.html (accessed on September 22, 2013). 
(13) Vidal, J. UN accused of ignoring 500,000 Chernobyl deaths. The Guardian, March 25, 2006, http://www.theguardian.com/environment/2006/mar/25/energy.ukraine (accessed on September 22, 2013).

(14) Malko, M. Assessment of malignant neoplasms in European countries, Joint Institute of Power and Nuclear Research, National Academy of Sciences of Belarus, 2006, http://www.physiciansofchernobyl.org.ua/eng/Docs/Malko.pdf (accessed on September 22, 2013).

(15) Gofman, J. Radiation-Induced Cancer From Low-Dose Exposure, Chapter 24 - Chernobyl: A Crossroad in the Radiation Health Sciences, 1990, http://www.ratical.org/radiation/CNR/RIC/chp24F.html (accessed on September 22, 2013).

(16) UNSCEAR. Effects of lonizing Radiation: United Nations Scientific Committee on the Effects of Atomic Radiation UNSCEAR 2006 Report to the General Assembly, with Scientific Annexes; United Nations: New York, 2006; 137. http://www.unscear.org/unscear/en/publications.html (accessed on September 22, 2013).

(17) Del Tredici, R. At work in the fields of the bomb; Harper\&Row: New York, 1987; pp 132-134 (interview of Karl Z. Morgan by the author).

(18) European Committee on Radiation Risk. 2010 Recommendations of the ECRR, The Health Effects of Exposure to Low Doses of lonizing Radiation, Regulators' Edition; Green Audit, 2010, http://euradcom.org/2011/ecrr2010.pdf (accessed on September 22, 2013).

(19) Public meeting, April 22, 2009, Stockolm. Transcript: http://euradcom.org/2009/lesvostranscript.htm (accessed on September 22, 2013) ; video: http://www.youtube.com/watch?v=k2JFxnAkTW4 (accessed on September 22, 2013).

(20) IRSN. Health consequences of chronic internal contaminations by radionuclides - Comments on the ECRR report "The health effects of ionizing radiation exposure at low doses for radiation protection purposes" and IRSN recommendations; 2005, http://euradcom.org/2005/irsneng.pdf (accessed on September 22, 2013).

(21) Busby, C. Predicting the global health consequences of the Chernobyl accident - Methodology of the European Committee on Radiation Risk; Green Audit, April 24, 2011; p 6. http://www.euradcom.org/2011/chernhealthrept3.pdf (accessed on September 22, 2013). 
(22) Yablokov, A.; Nesterenko, V; Nesterenko, A. Chernobyl: Consequences of the Catastrophe for People and the Environment; Annals of the New York Academy of Sciences, 2009, pp 210-211.

(23) Stolmar, A. My Chernobyl - What's wrong with nuclear power and how to fix it; Aladar Stolmar: 2008; $p$ 35 (ISBN: 978-1-4392-2017-7).

(24) OECD Committee on the Safety of Nuclear Installations. Results of recent risk studies in France, Germany, Japan, Sweden and the United-States; March 1994; abstract. http://www.oecdnea.org/nsd/docs/1994/csni-r1994-10.pdf (accessed on September 22, 2013).

(25) IRSN. R\&D relative aux accidents graves dans les réacteurs à eau pressurisée : bilan et perspectives; La Documentation française, January 2007; p 6 (my translation from French). http://www.irsn.fr/FR/expertise/rapports expertise/Documents/surete/IRSN CEA Rapport RD-accidentgrave 2006.pdf (accessed on September 22, 2013).

(26) Seghal, B. Some large issues raised by the Fukushima accidents for the nuclear power enterprise, Royal Institute of Technology of Sweden. Presented at the 14th International Topical Meeting on Nuclear Reactor Thermalhydraulics, Panel "Lessons learned from the Fukushima Accident", September 27, 2011. http://nureth14.org/media/NURETH-

14 Panel_LessonsLearnedfromFukushimaAccident/Sehgal\%20Bal\%20Ra Some\%20Larger\%20lssues.pd f (accessed on September 22, 2013).

(27) Klingler C. Fukushima a montré que l'improbable est possible. La Recherche, no 453, June 2011, p 50 (my translation from French). http://www.larecherche.fr/savoirs/dossier/4-philippe-jamet-fukushima-amontre-improbable-est-possible-01-06-2011-87814 (accessed on September 22, 2013).

(28) Lam, P. Severe Nuclear Accidents: Now What?; Civic Exchange: Hong-Kong, April 2012; p 14, http://www.civic-exchange.org/wp/120430nuclear en (accessed September 22, 2013).

(29) Massachussetts Institute of Technology. The Future of Nuclear Power - An interdisciplinary MIT study; 2003; p 48 (calculation limited to US reactors). http://web.mit.edu/nuclearpower/pdf/nuclearpower-full.pdf (accessed on September 22, 2013).

(30) Morin M. Jacques Repussard « Le risque naturel met au défi la sûreté nucléaire ». Le Monde, April 6, 2011 (interview of J. Repussard by the author; my translation from French). http://www.lemonde.fr/cgibin/ACHATS/acheter.cgi?offre=ARCHIVES\&type item=ART ARCH 30J\&objet id=1153518\&xtmc=repuss 
$\underline{\operatorname{ard} \& x t c r=19}$ (accessed on September 22, 2013).

(31) Laponche, B. Sûreté des centrales nucléaires, Encyclopaedia Universalis.

http://www.universalis.fr/encyclopedie/nucleaire-surete-des-centrales-nucleaires/3-un-accident-nucleairemajeur-est-loin-d-etre-improbable/ (accessed on September 22, 2013).

(32) Lelieveld, J.; Kunkel, D.; Lawrence, M.G. Global risk of radioactive fallout after major nuclear reactor accidents, Atmos. Chem. Phys. [Online] 2012, 12, 4245-4258. http://www.atmos-chemphys.net/12/4245/2012/acp-12-4245-2012.pdf (accessed on September 22, 2013).

(33) Cochran T. Statement on the Fukushima Nuclear Disaster and its Implications for U.S. Nuclear Power Reactors, Joint Hearings of the Subcommittee on Clean Air and Nuclear Safety and the Committee on Environment and Public Works, United States Senate, National Resources Defense Council, April 12, 2011, pp 2-3. http://www.nrdc.org/nuclear/files/tcochran 110412.pdf (accessed on September 22, 2013).

(34) Diaz-Maurin, F. Fukushima: Consequences of Systemic Problems in Nuclear Plant Design. Economic and Political Weekly 2011, XLVI (13).

http://www.academia.edu/820734/Fukushima Consequences of Systemic Problems in Nuclear_Plant D esign (accessed on September 22, 2013).

(35) Shrader-Frechette, K. Fukushima, Flawed Epistemology, and Black-Swan Events. Ethics, Policy and Environment 2011, 14 (3), 267-272. http://www3.nd.edu/ kshrader/pubs/black-swan-2011.pdf (accessed on September 22, 2013).

(36) Kalalo, E.; Brenot, D. Rôles et limites des EPS, Contrôle, December 2003, no 155, p 42 (my translation from French). http://www.asn.fr/index.php/S-informer/Publications/La-revue-Controle/Dossiersde-Controle-2003/Controle-n-155-les-etudes-probabilistes-de-surete (accessed on September 22, 2013).

(37) IRSN. Synthèse du rapport de I'IRSN sur les études probabilistes de sûreté de niveau 1 développées par EDF dans le cadre du réexamen de sûreté associé à la troisième visite décennale des réacteurs de 1300 Mwe; May 10, 2012; p 1 (my translation from French). http://www.irsn.fr/FR/expertise/rapports gp/Documents/Reacteurs/IRSN Synthese-Rapport EPS1-VD31300.pdf (accessed on September 22, 2013).

(38) English powerpoint presentation of the Negawatt energy scenario : http://www.negawatt.org/telechargement/SnW11//Scenario negaWatt 2011 Presentation Anglais.pdf ; 
animated graphical presentation in French : http://www.negawatt.org/scenario/decouverte ; French synthesis : http://www.negawatt.org/telechargement/SnW11//Scenario negaWatt 2011-

Dossier de synthese-v20111017.pdf (all accessed on September 22, 2013). 